\title{
Real-Time Monitoring of the Heat of Transfer of a Homologous Series of $m$-Alkoxy Phenols from Isotonic Aqueous Solution to Bacterial Cells
}

\author{
P. L. O.Volpe ${ }^{*, a}$ and A. E. Beezer ${ }^{b}$ \\ ${ }^{a}$ Instituto de Química, Universidade Estadual de Campinas, CP 6154, 13084-970 Campinas-SP, Brazil \\ ${ }^{b}$ The School of Pharmacy, University of London, 29/39 Brunswick Square London WC1N 1AX, England
}

\begin{abstract}
O calor de dissolução de uma série homóloga de $m$-alcoxifenóis numa solução isotônica osmoticamente estável e no mesmo meio contendo em suspensão células de Escherichia coli foi obtido à $298 \mathrm{~K}$ usando um calorímetro de batelada diferencial de condução de calor. As curvas calorimétricas mostram uma dissolução inicial rápida do soluto, seguida por um processo exotérmico. A partir dos calores de solução, o calor de transferência $\left(\mathrm{Q}_{\mathrm{trs}}\right)$ destes compostos da solução aquosa para as células, foi calculado. $\mathrm{Q}_{\mathrm{trs}}$ é exotérmico e aumenta com a hidrofobicidade dos compostos, devido às conseqüências biológicas do processo de interação com a fase lipídica.
\end{abstract}

Heats of dissolution of a homologous series of $m$-alkoxy phenols in an osmotically stable isotonic solution and in the same media containing a suspension of Escherichia coli cells were obtained by a differential heat conduction batch calorimeter at $298 \mathrm{~K}$. The calorimetric curves show an initial rapid endothermic dissolution of the solute, followed by an exothermic process. From the heats of solution, the heat of transfer $\left(\mathrm{Q}_{\mathrm{trr}}\right)$ of these compounds from the aqueous solution to the cells was calculated. The heat of transfer is exothermic and increases with the hydrophobicity of the compounds due to the biological consequences of the interaction process with the lipidic phase.

Keywords: lipidic phase transfer, biological calorimetry, $m$-alkoxy phenols, Escherichia coli

\section{Introduction}

The importance of thermodynamic data for the characterization of drug action was emphasized in recent papers. ${ }^{1-4}$ There is much interest in the relationship between biological response, BR, and drug structure, and the parameter most frequently used to study this relationship is the partition coefficient $\mathrm{K}_{\mathrm{D}}{ }^{5}$ Values of $\mathrm{K}_{\mathrm{D}}$ for a wide range of structures have been determined, ${ }^{5}$ but usually at only one temperature. In a very few instances, more detailed thermodynamic data are available to describe the transfer of a molecule from aqueous to non-aqueous solvents.

Selection of the appropriate non-aqueous solvent to represent the properties of a biological system is, however, a serious problem. 1-Octanol is the most commonly used solvent for a wide variety of systems. The successful use of 1-octanol/water partition coefficients has been ascribed to its hydrophobic and hydrophilic properties ${ }^{6}$ and to its solvating and associating properties. ${ }^{7}$ However the matter is still open to investigation and no definite choice

\footnotetext{
*e-mail: volpe@iqm.unicamp.br
}

of an appropriate solvent can be made until the solution thermodynamics of such systems are known in much greater detail than it is at present.

Kinkel et $a l .{ }^{8}$ discussed the use of the van't Hoff isochore to deduce values of enthalpy change which is inappropriate when the solvent pair used for the partition studies has (i) high mutual solubility and (ii) molecular states which are temperature sensitive. They suggest that the 1-octanol/water system suffers such limitations. Beezer and co-workers ${ }^{9,10}$ have shown that the van't Hoff determined enthalpies of transfer of resorcinol monoethers from water to 1-octanol agree, within experimental errors, with the values determined directly by calorimetry. Beezer et al. ${ }^{11}$ published thermodynamic data which characterize the transfer of a homologues series of $m$-alkoxy phenols from water to 1-octanol, to heptane and to propylene carbonate. They also have investigated the solubility of individual $m$-alkoxy phenols in water-alcohol solvent systems where the alcohol was systematically varied. ${ }^{12}$ These data allowed the derivation of group contributions to the values of $\Delta \mathrm{G}$, $\Delta \mathrm{H}$ and $\Delta \mathrm{S}$, which describe the transfer process. Not only was it possible to establish group contributions, but it also 
proved ${ }^{14}$ to derive, from the empirical Collander equation, a solvent scaling factor which may allow "ranking" of nonaqueous solvents for use in transfer studies. Thermodynamic parameters for transfer processes appear ideally suited to test the suitability of such solvents, whilst calorimetry enables direct measurement of the heat of transfer $\left(Q_{t r s}\right)$ that accompanies physical and chemical changes.

There are, at present, no criteria apart from complete quantitative structure-activity relationship (QSAR) studies, by which the correlation between a solvent system and a biological system (e.g. microorganism, tissues, isolated cells and whole organs) can be judged. The problem still remains, however, to establish that bulk solvents do indeed behave like biological membranes, at least as far as the transfer process is concerned. Likewise there is no report in the literature on the evaluation of the heat effect caused by transfer of drugs from aqueous solution to living non-growing microorganism cells as a function of time. Hence, we have attempted in this work to analyze, by batch calorimetry, the heat effect accompanying the dissolution, interaction and consequent transfer of phenols, as a function of time, from aqueous solution to living, non-growing Escherichia coli cells suspended in isotonic Ringer's solution. These cells are as close to non-metabolizing cells as can be achieved. ${ }^{14}$

\section{Experimental}

The methoxy and ethoxy derivatives of resorcinol were purchased from Eastman Kodak Co. Ltd. and were distilled under vacuum before use. The other $m$-alkoxy phenols were synthesized and purified as described previously. ${ }^{9}$ The inocula of Escherichia coli (NCTC 10418) were grown and harvested, and then stored in ampoules in liquid nitrogen following viable counting as previously described.$^{15}$ Following thawing of an ampoule of the $E$. coli suspension,

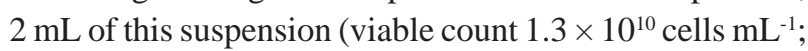
recovery $>95 \%$ ) were added to $10 \mathrm{~mL}$ of isotonic Ringer's solution which had been previously treated with $\mathrm{N}_{2}$ to make it oxygen-free. Heat effect measurements were made in an isothermal differential twin, heat conduction LKB batch microcalorimeter (Type 10700-1, LKB Produkter $\mathrm{AB}$, Bromma, Sweden) suitably modified to permit sequential addition of titrant to titrand without disturbance of the calorimeter. The design and testing of the titration assembly together with detailed operating procedures have been described. ${ }^{16}$ Six $\mathrm{mL}$ of the E. coli suspension were placed into the calorimeter sample and reference vessels and left to equilibrate for $1 \mathrm{~h}$. The calorimetric system shown in Figure 1 consists of a rotating unit suspended in a thermostated air bath at $298 \mathrm{~K}$. The rotating unit consists
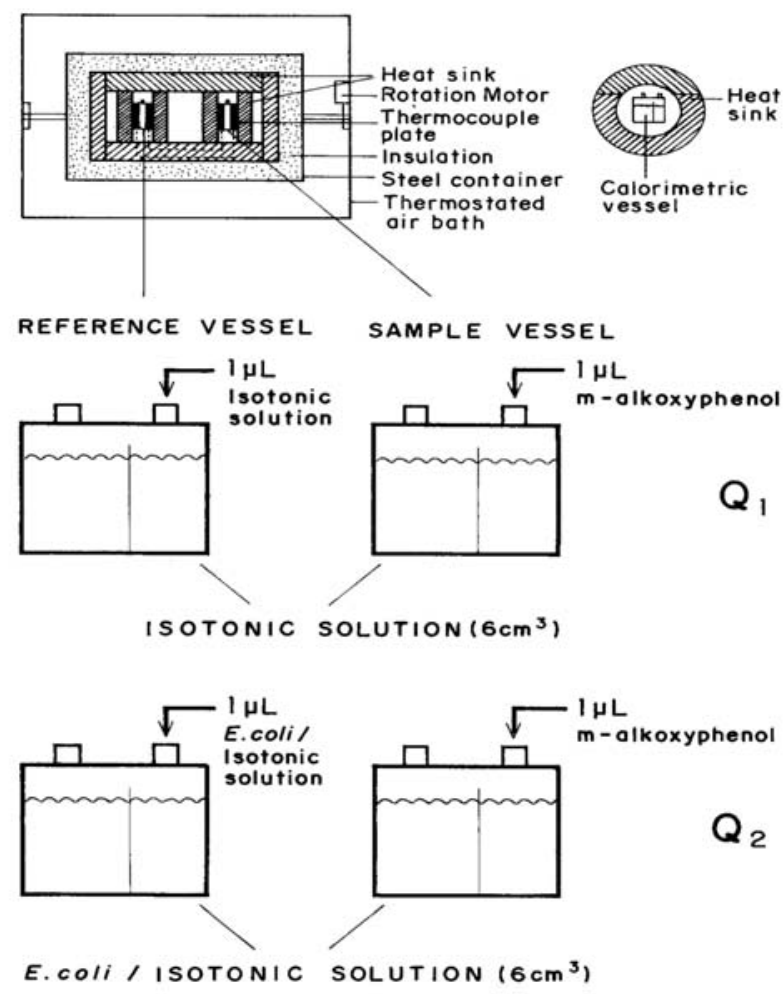

Figure 1. Schematic diagram of the isothermal differential twin heat conduction batch calorimeter with sample and reference vessels.

of a cylindrical heat sink, in which the two separate sample and reference reaction vessels, thermopiles, microlitersyringes and arrangements for the temperature control are housed. A $1 \mu \mathrm{L}$ injection of the solute ( $m$-alkoxy phenol) was added to the sample vessel and simultaneously $1 \mu \mathrm{L}$ of Ringer's solution was added to the reference vessel and $\mathrm{Q}_{2}$ was experimentally determined (see Figure 1). The heat of solution of this homologous series of phenols in Ringer's solution $\left(\mathrm{Q}_{1}\right)$ was measured in parallel experiments. The calorimetric rotation unit shown in Figure 1 where both vessels are contained was kept rotating to ensure uniformity of the cell suspensions and to avoid cell sedimentation. The drum was rotated $360^{\circ}$ and then back $360^{\circ}$ with a period of 30 seconds. No serious thermal consequences resulted from continuous rotation of the calorimetric drum. Noise increased slightly but no drift in baseline could be observed over a $1 \mathrm{~h}$ period as can be seen in Figure 2. The concentrations of the phenols after injection into $E$. coli suspension were $m$-methoxy, $1.59 \mathrm{mmol} \mathrm{L}^{-1} ; m$-ethoxy, $1.38 \mathrm{mmol} \mathrm{L}^{-1} ; m$-propoxy, $1.21 \mathrm{mmol} \mathrm{L}-1 ; m$-butoxy, $1.08 \mathrm{mmol} \mathrm{L}^{-1}$ and $m$-pentoxy $0.98 \mathrm{mmol} \mathrm{L}^{-1}$.

\section{Results and Discussion}

Figure 2 shows the calorimetric curves for dissolution of pure $m$-alkoxy phenols in the isotonic solution and 


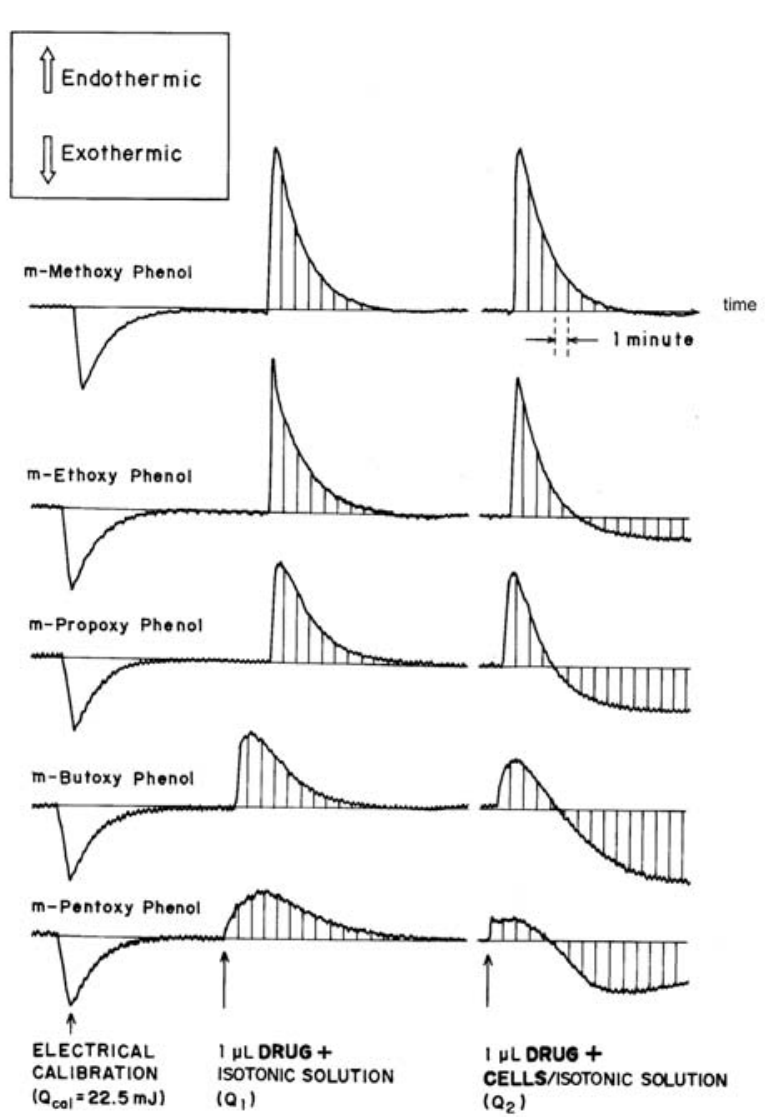

Figure 2. Thermograms for the addition of pure liquid solute to isotonic aqueous solution and to aqueous non-growing suspension of E.coli.

in the isotonic solution containing the suspended cells in comparison with the electrical calibration of the calorimeter. From the scheme of reactions described below, the desired heat effect for the transfer of the drug from isotonic medium to the bacteria cells $\left(\mathrm{Q}_{\mathrm{trr}}\right)$ can be calculated from experimentally accessible heats $\mathrm{Q}_{1}$ and $\mathrm{Q}_{2}\left(\mathrm{Q}_{\mathrm{trs}}=\mathrm{Q}_{2}-\mathrm{Q}_{1}\right)$ :

\section{Drug (pure liquid) + Isotonic Solution $\rightarrow$ Drug in Isotonic Solution Heat, $\mathrm{Q}_{1}$ (experimental)}

Drug (pure liquid) + E.coli cells in Isotonic Solution $\rightarrow$ Drug/cells in Isotonic Solution

Heat, $Q_{2}$ (experimental)

\section{Drug/Isotonic Solution + Cells/Isotonic Solution $\rightarrow$ Drug/cells in Isotonic Solution \\ Heat, $Q_{\text {trs }}$ (calculated)}

The heat effects of drug dissolution in isotonic solution $\mathrm{Q}_{1}$ and in isotonic solution containing the suspension of microorganism cells, $\mathrm{Q}_{2}$, were calculated by comparing the

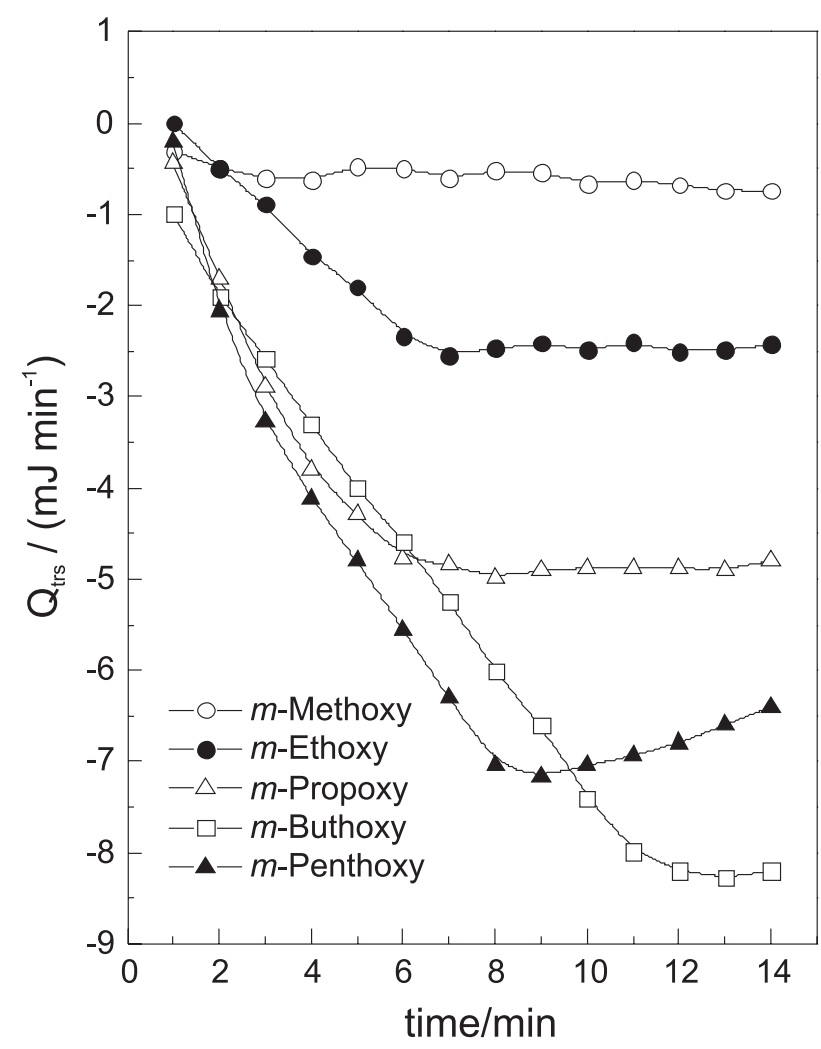

Figure 3. Heat of transfer $\mathrm{Q}_{\text {trs }} v s$. time curves for the homologous series of $m$-alkoxy phenols.

area of the calorimetric curves of each process with the area due to the electrical calibration. The differences between the heat effects $Q_{2}$ and $Q_{1}$ were calculated at one-minute intervals and are shown in Figure 3.

The heats of dissolution of this series of $m$-alkoxy phenols in aqueous isotonic solution are all endothermic and become less endothermic as the alkyl chain length increases, as can be seen in Figure 2. This observation is in agreement with the solution enthalpy data for these compounds in pure water obtained by Beezer et al. ${ }^{10}$ Figure 2 also shows that after the initial endothermic peak due to the dissolution of the drug into the isotonic aqueous solution containing the living cells, the heat effect becomes more exothermic with time. This observation is consistent with the data for the enthalpies of solution obtained by Beezeer et al. ${ }^{10}$ for the alkoxy phenols in pure 1-octanol, which are all exothermic.

We have assumed in the evaluation of the $\mathrm{Q}_{\mathrm{trs}}$ values as a function of time that a quasi-equilibrium state exists for the transfer of the solute from water to cellular compartment/ receptor. The time for this transfer to reach a steady state is about 13 minutes (Figure 3).

The rapid process, which leads to endothermic values of $\mathrm{Q}_{2}$ in Figure 2 is the result of dissolution of the drug. The course of the initial, rapid endothermal process is almost 
identical with the time course observed in the dissolution process in the absence of cells. The exothermic portion of the experimental $Q_{\text {trs }}$ vs. time curves increases with the hydrophobicity of the drug. We take this slow exothermal power evolution to be due to processes consequent to the transfer.

Figure 3 shows that the values of the heat transfer $\left(\mathrm{Q}_{\mathrm{trs}} / \mathrm{mJ}\right)$ become more exothermic as the hydrophobicity of the drug increases. From Figure 3 it can be seen that when the process reaches the steady state at about 13 minutes and the value of the heat transfer $Q_{t r s}$ has a linear correlation with the number of $\mathrm{CH}_{2}$ groups of the hydrocarbon side chain of these compounds until the compound $m$-butoxy phenol. This behavior is in agreement with the biological activity data of these compounds on the respiration of Escherichia coli and Chromobacterium violaceum obtained by flow calorimetry. ${ }^{15,17}$ The discontinuity of the behavior for $\mathrm{Q}_{\text {trs }}$ observed for the highest member of the $m$-alkoxy phenol series may be due to the aggregation of $m$-penthoxy phenol in the aqueous solution, which may lead to a decrease of the transfer rate of molecules across the bacterial cell membrane.

\section{Acknowledgments}

The authors thank CNPq - Conselho Nacional de Desenvolvimento Científico e Tecnológico-Brazil, for financial support and Professor Fred Yukio Fujiwara for critical comments.

\section{References}

1. Klopman, G.; Zhu, H.; Mini-Rev. Med. Chem. 2005, 5, 127.
2. Kramer, S. D.; Wunderli-Allenspach, H.; Il Farmaco 2001, 56, 145.

3. Avdeef, A.; Curr. Top. Med. Chem. 2001, 1, 277.

4. Camenish, G.; Folkers, G., van de Waterbeemd, H.; Pharm. Acta Helv. 1996, 7, 309.

5. Leo, A.; Hansch, C.; Elkins, D.; Chem. Rev. 1971, 71, 525.

6. Kubinyi, H.; Prog. Drug Res. 1979, 23, 97.

7. Smith, R. N.; Hansch, C.; Ames, M. M. J.; J. Pharm. Sci. 1975, 64, 599.

8. Kinkel, J. F. M.; Tomlinson, E.; Smith, P.; Int. J. Pharm. 1981, 9, 121.

9. Beezer, A. E.; Hunter, W. H.; Storey, D. E.; J. Pharm. Pharmacol. 1980, 32, 815.

10. Beezer, A. E.; Hunter, W. H.; Storey, D. E.; J. Pharm. Pharmacol. 1983, 35, 350.

11. Beezer, A. E.; Volpe, P. L. O.; Hunter, W. D.; J. Chem. Soc. Faraday Trans. 1 1986, 82, 2863.

12. Beezer, A. E.; Volpe, P. L. O.; Lima, M. C. P.; Hunter, W. D.; J. Solution Chem. 1986, 15, 341.

13. Beezer, A. E.; Gooch, C. A.; Hunter, W. H.; Volpe, P. L. O.; J. Pharm. Pharmacol. 1987, 39, 774.

14. Beezer A. E.; Volpe, P.L.O.; Gooch, C. A.; Hunter, W. H.; Miles, R. J.; Int. J. Pharm. 1986, 29, 237.

15. Volpe, P. L. O.; J. Braz. Chem. Soc. 1997, 8, 343.

16. Beezer, A. E.; Hunter, W. H.; Lipscombe, R.; Newell, R. D.; Storey, D. E.; Thermochim. Acta 1982, 55, 345.

17. Oliveira, A. D.; Lisboa, C. P.; Volpe, P. L. O.; Thermochim. Acta 2005, 436, 26.

Received: January 9, 2008

Web Release Date: July 25, 2008

FAPESP helped in meeting the publication costs of this article. 